\title{
Frozen voices: Women, silence and Antarctica
}

\author{
Jesse Blackadder ${ }^{1}$
}

This chapter explores a different kind of Antarctic silence: the silencing of certain stories and voices. It's the silence of the earliest female travellers to Antarctica.

The voices of the earliest female travellers are silent and their stories remain untold, partly because there's no place for them in the dominant Antarctic narrative of exploration and conquest. Reimagining them through fiction is one way - though with potential pitfalls - to 'unfreeze' those stories.

The history of Antarctic exploration is about the adventures of men, particularly those in the so-called 'Heroic Age' from approximately 1897 to 1922. The great names of polar exploration, like Scott, Shackleton, Amundsen and Mawson, are well known and the mythology of their exploration, successes and failures still fascinates people today. The themes of their exploration narratives concerned heroism, conquest, suffering and male bonding.

Arguably the most powerful exploration story was the race between the British Scott and the Norwegian Amundsen to the South Pole. Polar scholar Elena Glasberg says 'This celebrated competition was motivated by all the familiar elements that shaped exploration history: the cultures of nationalism, imperial science, and male adventure' ${ }^{2}$ Those defining moments of Antarctic history were masculine, and issues of gender were stamped on the landscape from the start.

Antarctic historian Tom Griffiths describes it thus: 'There was something spiritual about male comradeship, something pure about distant yearning and asexual love, and something incontrovertibly masculine about frontiering. The ice was their own inviolable space. In Antarctica, the presence of women could diminish a man. In their absence, one might prove oneself worthy of them'. ${ }^{3}$

This has led to a primary narrative of Antarctica, a tale of suffering, competition, and achieving the all-important 'first'. No one just ends up in Antarctica - there is always a journey of some sort to get there. These 'terrible journeys', such as

\footnotetext{
1 Dr Jesse Blackadder, Writing \& Society Research Centre, University of Western Sydney, 3 Muli Court, Myocum, NSW 2481, jesse@blackadder.net.au.

2 E Glasberg (2002) 'Refusing history at the End of the Earth: Ursula Le Guin's "Sur" and the 2000-01 Women's Antarctica Crossing'. Tulsa Studies in Women's Literature 21(1): 99-121, p. 101.

3 T Griffiths (2007) Slicing the silence. UNSW Press, Sydney, p. 214.
} 
Cherry-Garrard's 'worst journey in the world', Shackleton's epic journey to save himself and his men, the competitive journey to the South Pole between Scott and Amundsen, and Mawson's lone trek for survival, function as Antarctica's formation myths. The linear journey of exploration, the classic 'hero's journey', has become a blueprint for Antarctic stories.

Where did women fit into this masculine space?

According to polar scholar Elizabeth Leane, Antarctica itself was constructed as feminine in its literature. ${ }^{4}$ In some Antarctic narratives from the early 20th century 'the continent resembles nothing so much as a monstrous feminine body that threatens to engulf the unwary male explorer' $\left(2009\right.$, p. 511). ${ }^{5}$ The heroic phase was characterised by expedition writing that characterised the continent as 'an aloof virginal woman to be won through chivalrous deeds' ${ }^{6}$

This is clearly expressed in the cartoon 'Waiting to be Won', from Punch in 1875, which depicts the 'White Ladye of the Pole'. The verses printed with the cartoon said:

But still the white Witch-Maiden that sits above the Pole

In the snow-bound silver silence whose cold quells aught but soul

Draws manly hearts with strange desire to lift her icy veil

The bravest still have sought her, and will seek, whoever fail. ${ }^{7}$

Although this image relates to the North Pole, Leane points out that 'both icescapes tend to be feminised when viewed as fields of endeavour' ${ }^{8}$

Women's entry into this space was obviously problematic. On a physical level women were actively — in fact, strenuously - excluded from Antarctica in the first century of its history. Access to Antarctica in that time was controlled by money, race and gender. None of the great heroic era explorers took women with them.

Although opportunities for women were severely restricted, the desire for adventure wasn't only a masculine one. Among Shackleton's records is this letter from three young women who asked to join his expedition:

We are three strong healthy girls, and also gay and bright, and willing to undergo any hardships, that you yourself undergo. If our feminine garb

\footnotetext{
4 E Leane (2009) 'Placing women in the Antarctic literary landscape'. Signs: Journal of Women in Culture and Society 34(3): 509-14, p. 510.

5 Leane (2009) 'Placing women in the Antarctic literary landscape', p. 511.

6 Leane (2009) 'Placing women in the Antarctic literary landscape', p. 511.

7 Reproduced in F Spufford (1997) I may be some time: ice and the English imagination. Picador, New York, p. 178.

8 Leane (2009) ‘Placing women in the Antarctic literary landscape', p. 510.
} 
is inconvenient, we should just love to don masculine attire. We have been reading all books and articles that have been written on dangerous expeditions by brave men to the Polar regions, and we do not see why men should have the glory, and women none, especially when there are women just as brave and capable as there are men. ${ }^{9}$

Newspaper articles report that women applied to be included in Antarctic expeditions in 1919 at the tail end of the heroic era:

\section{THE ANTARCTIC. ANOTHER EXPEDITION.}

WOMEN WANT TO GO.

LONDON October 18.

Captain Cope is inviting applications from experts in the following sciences to accompany his expedition to the Antarctic regions:Geology, meteorology, biology, photography, surgery, cartography, and hydrography. The party will number 51, of whom 17 will be engaged on shore work. A number of the members of the expeditions which accompanied Captain Sir R. F. Scott and Captain Sir Ernest Shackleton have joined the expedition. Several women were anxious to join, but their applications were refused. ${ }^{10}$

Antarctic exploration moved into the mechanical era in the 1920s, using planes and motorised ships to further exploration goals. But women were still actively excluded from participating.

Twenty-five women applied to join Mawson's British, Australian and New Zealand Antarctic Research Expedition (BANZARE) in $1929^{11}$ and in 1937 the extraordinary number of 1,300 women applied to join the proposed British Antarctic Expedition. ${ }^{12}$ None were successful in being permitted to travel to Antarctica.

Women were known to have sailed to the Far South as companions on whaling and sealing ships plying their trade around the wild subantarctic islands in the 19th century, though their names were often not recorded. ${ }^{13}$ In the mechanical era, it was possible for women to travel to Antarctica in greater safety and comfort as companions, providing support, care and domestic tasks. As in the history of American deep-sea whaling, generally the first women to go were the wives of the captains.

9 Reproduced in Spufford (1997) I may be some time, p. 144.

10 The Advertiser 10 October 1919, p. 7. 'The Antarctic: another expedition: Women want to go'. Retrieved from http://nla.gov.au/nla.news-article5633923.

11 The Argus (1929), p. 9.

12 The Argus 3 April 1937, p 17. 'Women want to go to pole: 1,300 applications: "No," says leader'. Retrieved from http://nla.gov.au/nla.news-article11053800.

13 E Chipman (1986) Women on the ice: a history of women in the Far South. Melbourne University Press, Melbourne, p. 11. 
The first woman recorded to have set foot on Antarctica was Caroline (also spelt Karoline) Mikkelsen, who accompanied her husband south in $1935 .{ }^{14}$ He had been working as a captain in the Norwegian whaling fleet on ships owned by Lars Christensen, with instructions to look for Antarctic lands that could be annexed for Norway. During their voyage a group including Caroline went ashore for several hours, raised the Norwegian flag, built a cairn, had afternoon tea and then returned to the ship.

Caroline neatly fitted in to the small role that could be allotted to women in the dominant Antarctic narrative: a domestic companion who was conveyed there by her husband and who set foot on the continent as an appendage to him. Although her landing wasn't publicised at the time, her 'first' was later reclaimed and now appears in Antarctic lists and timelines everywhere, as well as in books and articles by feminist scholars. If you Google 'first woman on Antarctica', hers is the name that comes up.

However, the reality's not so simple. As Chipman says, "many of the "firsts" in the Far South are suspect and coloured by prevailing attitudes' (1986 p. 6). ${ }^{15}$

Four women are known to have gone to Antarctica before Caroline, but they've been largely overlooked. I'd like to tell you something of their story.

The Norwegian Ingrid Christensen first went to the Antarctic in 1931 (four years before Caroline) when she was 38 and had six children, whom she left at home. Her husband Lars was an entrepreneur who owned a large pelagic whaling fleet and personally funded much of Norway's Antarctic exploration. Ingrid went as his companion on the refuelling vessel for his factory fleet, a relatively privileged position. Ingrid and her companion Mathilde Wegger were, in 1931, the first identifiable women known to have seen Antarctica. ${ }^{16}$ However, that year the expedition did not find a suitable landing site. Ingrid didn't achieve that all-important 'first footprint'. Mathilde faired even less well in recorded history. She was a widow and presumably went to keep Ingrid company - a role even more lowly than Ingrid's own - the companion of the companion. Chipman (1986) mentions her by name and includes a photograph of the two women together, but little other information about Mathilde survives in English-language history.

14 Mikkelsen is reported as the first woman to land on Antarctica in publications including the Norwegian Main Events in the History of Antarctic Exploration (Bogen (1957) p. 85), the Australian A History of Antarctica (Stephen Martin (1996) State Library of NSW Press, Sydney, p. 194); the English Encyclopaedia of Antarctica and the Southern Oceans (B Stonehouse (2002), John Wiley and Sons, Chichester) and the American Encyclopedia of the Antarctic (B Riffenburgh (2007) Routledge, New York, vol. 1) as well as on numerous websites.

15 Chipman (1986) Women on the ice, p. 6.

16 Chipman (1986) Women on the ice, p. 72. 
Two years later, in 1933 Ingrid and Lars travelled to Antarctica for the second time, again leaving their children at home. This time Ingrid's companion was Lillemor (Ingebjorg) Rachlew, a woman who kept a lively diary of their trip, took photographs and from her own account, participated energetically in the voyage.

Here's one of Lillemor's descriptions:

At one time during the morning it became a little calmer and I made my way along to the verandah — as we called the built-in deck beneath the captain's bridge - with my cine camera under my arm, to see if I could get any snaps of what could be seen of the after-deck between the waves. Suddenly the ship lurched violently and I fell and rolled in snow slush right across the verandah, coming to anchor with a crash on the port side, in the midst of some chairs and tables that were lashed securely there. Once there, I made use of the opportunity to take some snaps, and I very much hope they will be good - I'm sure I deserve it after all I went through! ${ }^{17}$

Perhaps in the original diaries there might have been more personal reflection or some clues about what motivated Lillemor to set out on the journey. But although Lars quotes from Lillemor's diary extensively in his book, so far I've found no trace of her diaries still existing today.

An article about Lillemor and Ingrid appeared in a 1933 French journal carrying Lillemor's photographs ${ }^{18}$ but that's one of the few contemporary media reports of their activities. Like Mathilde, Lillemor didn't have a place in the main Antarctic narrative.

Accompanied by a woman called Ingeborg Dedichen, Ingrid went to Antarctica for the third time in 1933-34 when the refuelling vessel Thorshavn circumnavigated the continent on a lengthy voyage. ${ }^{19}$ Once again they didn't manage a landing anywhere. This was one of the most remote places on earth and the conditions were unpredictable and dangerous, so landing wasn't a given.

The following season, 1935, Caroline Mikkelsen was in luck. With good conditions, she made the landing. ${ }^{20}$ She also made her own decision around

17 As cited in L Christensen (1935) Such is the Antarctic (transl. E Jayne). Hodder and Stoughton, Great Britain, p. 81 .

18 C Rabot (1934) 'Voyage d'une femme dans L'Antarctique' ('Travels of a woman in the Antarctic').

L'Illustration, 4741 (13 January): 52-53, p. 52.

19 Chipman (1986) Women on the ice, p. 172.

20 H Bogen (1957). 'Main events in the history of Antarctic exploration'. Norwegian Whaling Gazette, Sandefjord, p. 85 . 
'silence'. Two years after the landing, her husband died. Caroline remarried and chose not to talk about her Antarctic experiences 'to spare his feelings' ${ }^{21}$ She kept silent about her story for decades.

Ingrid's fourth and final voyage was in 1936, after Caroline's landing. Lillemor went again as her companion and this time Ingrid took her youngest daughter Sofie, who was then 18. Another woman, Solveig Wideroe, whose husband was an aviator on the ship, was also with them. They carried out aerial exploration and Ingrid became the first woman to see Antarctica from the air. They attempted to go ashore where Caroline Mikkelsen had landed, but as soon as they got into the motor boat, bad weather came up. They were nearly swamped and had to turn back without landing. ${ }^{22}$

It seems like Ingrid's efforts to land were jinxed, and according to most recorded history, her Antarctic story ends then. Chipman, who focused on creating a complete list of women who travelled there, doesn't follow her journey any further. Lisbeth Lewander, writing about women who travelled to Antarctica between 1930 and 1990, doesn't mention any of these women. ${ }^{23}$ Barbara Land calls Ingrid 'the whaling magnate's wife' and gives her less than two sentences in the history of female visitors to Antarctica. ${ }^{24}$

However, later on that voyage the four women - Ingrid, her daughter Sofie, Lillemor and Solveig — did actually go ashore at Scullin Monolith, with Lars. Because this landing wasn't a 'first', no fuss was made of it. Lars didn't mention the women at all when he set down his personal excitement at achieving this goal. ${ }^{25}$ What Ingrid thought about it was never recorded.

To all intents and purposes, Ingrid's four trips to Antarctica were forgotten. In fact the whole unimportant matter of the first woman to land on Antarctica rested there until the 1980s when a number of books appeared about women's experiences in Antarctica, scholars started exploring issues of gender around Antarctica, and Caroline Mikkelsen's landing was brought out of obscurity and put on the record.

21 D Patterson (1995) 'The Vestfold Hills: the Norwegian connection'. ANARE News Spring/Summer: 4344, p. 44.

22 L Christensen (1937) My last expedition to the Antarctic. Johan Grundt Tanum, Oslo, p. 9.

23 L Lewander (2009) 'Women and civilisation on ice'. Cold matters: cultural perceptions of snow, ice and cold. Umeå University and the Royal Skyttean Society Monograph no 1, 89.

24 B Land (1981) The new explorers: women in Antarctica. Dodd, Mead \& Company, New York, p. 17.

25 L Christensen (1938) 'Charting the Antarctic'. American Scandinavian Review 26: 209-21, p. 217. 
Then in 1998 some Australian geographic researchers (Norman, et al. 1998) took a fresh look at evidence of Klarius Mikkelsen's 1935 landing. ${ }^{26}$ The Norwegian cairn from 1935 had been rediscovered by people working at Davis station. ${ }^{27}$ The landing site, it transpired, was on an island.

In the world of polar exploration, landing on an island is of lesser value than landing on the mainland. Suddenly it looked like Caroline wasn't the first one to have landed on the mainland. So who was? Norman et al. say:

The irony of the answer is manifest. Ingrid Christensen, Ingebjorg [Lillemor] Rachlew, Solveig Wideroe and Augusta Sophie Christensen, all landed at Klarius Mikkelsen Mountains (now Scullin Monolith) on 30 January 1937 [Bogen, 1957], but which of the 'ladies' touched the land first remains unknown. Ingrid Christensen was the first mentioned, but were her feet first ashore? ${ }^{28}$

Ingrid, Lillemor, Sofie or Solveig. Any of them might have been the first woman to land on the Antarctic continent, though at the time they wouldn't have known it, still believing Caroline had taken the honour. And so it seems that no record was made of the all-important first footstep in the ship's log or elsewhere.

This news didn't exactly set the world of polar studies on fire. No one else showed much interest in this aspect of the work of Norman and his colleagues, and once again, there the matter rested.

Within the dominant narrative of exploration and conquest of Antarctica, the journeys of all of these women have remained less than secondary. Travelling to Antarctica as companions of men, or even less importantly, as companions of women, their 'first' just doesn't make it. Having been conveyed there by men, virtually as baggage, what story could they possibly have to tell? It's likely even Caroline felt this, as she didn't speak about her Antarctic experiences until the 1990s when she was tracked down by an Australian researcher Diane Patterson - herself the first female leader of an Australian Antarctic base. ${ }^{29}$

According to Leane, who categorises Antarctic literature into three stages, the most recent stage is one 'in which Antarctic literature by and about women has flourished and broadened, informed by women's burgeoning opportunities to experience the continent' ${ }^{30}$ However, even modern women's contributions to Antarctic literature are still profoundly influenced by the masculine epic

\footnotetext{
26 FI Norman, JAE Gibson and JS Burgess (1998) ‘Klarius Mikkelsen's 1935 landing in the Vestfold Hills, East Antarctica: some fiction and some facts'. Polar Record 34(191): 293-304.

27 Norman et al. (1998) ‘Klarius Mikkelsen's 1935 landing in the Vestfold Hills', p. 297.

28 Norman et al. (1998) 'Klarius Mikkelsen's 1935 landing in the Vestfold Hills', p. 301.

29 Patterson (1995) 'The Vestfold Hills', p. 44.

30 Leane (2009) 'Placing women in the Antarctic literary landscape', p. 510.
} 
journey of discovery narrative. One example in fiction is Ursula Le Guin's short story 'Sur', published in the New Yorker in 1982. ${ }^{31}$ Her feminist reworking of the heroic exploration myth imagines 'an alternative history of Antarctic exploration not premised on conquest, nationalism, fame or race to finish' ${ }^{32}$

Yet Glasberg argues that Le Guin's narrative, about a team of South American women beating Scott and Amundsen to the pole but leaving no trace of their expedition, functions to renarrativise masculine exploration history, and 'documents the very history it seeks to critique. Can Le Guin project a feminist fantasy of prior arrival and yet refuse the complicities of masculine teleologies of conquest?'.$^{33}$ This tendency appears in other Antarctic novels and memoirs by women, such as Antarctic navigation ${ }^{34}$ and Terra incognita: travels in Antarctica, ${ }^{35}$ which consciously engage with, respond to and re-enact the masculine myths of Antarctica.

My Doctor of Creative Arts (DCA) project included the novel Chasing the Light, ${ }^{36}$ about Ingrid and her journey to Antarctica. The starting point for the story, the thing that fascinated me, was that Ingrid travelled to Antarctica four times, but missed out on being the first woman to land and therefore was forgotten by history. At the start of my research, and as I learned more about her, I felt a strong urge to excavate her story and tell it to a wider audience. My intent was to use fiction in developing her character and exploring her possible emotional journey, but to base the novel as closely as I could on the known historical facts about her.

Two issues arose for me in the course of the research. First was the challenge of fictionalising history. Le Guin created an entirely fictional cast, whereas I was stepping into that tricky territory of plundering history in search of a good story, the very thing for which historian Inga Clenndinnen took Kate Grenville to task. ${ }^{37}$ I started out by using everything I could find about Ingrid and filling in the considerable blanks with my own imagination - a risky undertaking in relation to a person who died in 1976 and has living descendants. How far could I go in recreating her story if I wished to have the creative freedom and imagination to explore all aspects of it? Clendinnen's critique of novelists making free with stories from history is that empathy alone is not enough to allow novelists to understand characters who are widely separated from them by time, space and culture. She says it leads to the illusion of understanding,

31 Le Guin, U (1982) 'Sur'. New Yorker 1 February, pp. 38-46.

32 Leane (2009) 'Placing women in the Antarctic literary landscape', p. 510.

33 Glasberg (2002) 'Refusing history at the End of the Earth', p. 111.

34 Arthur, E (2005) Antarctic Navigation. Bloomsbury Publishing, London.

35 Wheeler, S (1996) Terra incognita: travels in Antarctica. Jonathan Cape, London.

36 Blackadder, J (2013) Chasing the light: a novel of Antarctica. HarperCollins, Sydney.

37 Clendinnen, I (2006) 'The history question: Who owns the past?' Quarterly Essay vol. 23. Black Inc, Melbourne. 
when in fact the task of true understanding requires long observation, cool thought and the ability to resist rather than indulge intuition. ${ }^{38}$ And of course there is the large ethical question of drawing on a known life and using it as a leaping-off point, with all the complications of that.

Second, I realised I was also deeply influenced by the pervasive Antarctic narrative of the exploratory journey of conquest. I was anything but immune to it. I found myself transposing Ingrid and Caroline into the classic Scott/ Amundsen Antarctic narrative. That hero's journey with its inherent drama lent itself irresistibly to these women's stories. Caroline, as the quiet, efficient victor of the competition, stood in for Amundsen, who started later, was better prepared and ultimately won the prize of the South Pole. Ingrid became the tragic and heroic figure of Scott, the one who arrived second, who stood in her equivalent of Scott's 'awful place' knowing that she'd failed in achieving even her own modest first.

These were sobering reflections that resulted in shifts in the creative direction. I decided not to write the novel from Ingrid's point of view, but to expand it into a third-person narrative about her, Mathilde and Lillemor. I chose to create a fictional voyage that incorporated elements of all four of Ingrid's reallife voyages. These were difficult decisions, and meant to an extent letting go of the notion of rescuing Ingrid from history's cracks. My challenge was to proceed with the writing in a way that remained conscious of the influence of that great Antarctic narrative over my story, and to both reflect on it and allow other narratives to emerge. 
This text is taken from Antarctica: Music, sounds and cultural connections, edited by Bernadette Hince, Rupert Summerson and Arnan Wiesel, published 2015 by ANU Press, The Australian National University, Canberra, Australia. 